BMJ Open Sport \& Exercise Medicine

\section{Dehydration is how you define it: comparison of 318 blood and urine athlete spot checks}

Tamara D Hew-Butler, Christopher Eskin, Jordan Bickham, Mario Rusnak, Melissa VanderMeulen

To cite: Hew-Butler TD, Eskin C, Bickham J, et al. Dehydration is how you define it: comparison of 318 blood and urine athlete spot checks. BMJ Open Sport \& Exercise Medicine 2018;4:e000297. doi:10.1136/ bmjsem-2017-000297

Accepted 19 December 2017

\section{ABSTRACT}

Clinical medicine defines dehydration using blood markers that confirm hypertonicity (serum sodium concentration $\left.\left(\left[\mathrm{Na}^{+}\right]\right)>145 \mathrm{mmol} / \mathrm{L}\right)$ and intracellular dehydration. Sports medicine equates dehydration with a concentrated urine as defined by any urine osmolality (UOsm) $\geq 700 \mathrm{mOsmol} / \mathrm{kgH}_{2} \mathrm{O}$ or urine specific gravity (USG) $\geq 1.020$.

Objective To compare blood versus urine indices of dehydration in a cohort of athletes undergoing routine screenings.

Methods 318 collegiate athletes (193 female) provided blood and urine samples and asked to rate how thirsty they were on a 10-point visual analogue scale. Serum was analysed for $\left[\mathrm{Na}^{+}\right]$, while serum and UOsm were measured using an osmometer. USG was measured using a Chemstrip. Data were categorised into dehydrated versus hydrated groupings based on these UOsm and USG thresholds.

Results Using U0sm $\geq 700 \mathrm{~m} 0 \mathrm{smol} / \mathrm{kgH}_{2} 0$ to define dehydration, $55 \%$ of athletes were classified as dehydrated. Using any USG $\geq 1.020$ to define dehydration, $27 \%$ of these same athletes were classified as dehydrated. No athlete met the clinical definition for dehydration (hypertonicity; serum $\left[\mathrm{Na}^{+}\right]>145 \mathrm{mmol} / \mathrm{L}$ ). Normonatremia (serum $\left[\mathrm{Na}^{+}\right]$between $135 \mathrm{mmol} / \mathrm{L}$ and $145 \mathrm{mmol} / \mathrm{L}$ ) was maintained in $99.7 \%$ of athletes despite wide variation in U0sm (110-1298 m0smol/ $\mathrm{kgH}_{2}$ 0). A significant correlation was confirmed between serum $\left[\mathrm{Na}^{+}\right]$versus UOsm $(r=0.18 ; P<0.01)$, although urine concentration extremes did not reflect derangement in serum markers or thirst rating.

Conclusion Urine concentration thresholds classified $27 \%-55 \%$ of collegiate athletes as dehydrated, while no athlete was dehydrated according to blood $\left[\mathrm{Na}^{+}\right]$ measurement. Practitioners should caution against using urine indices to diagnose or monitor dehydration, because urinary output is a response rather than a reflection of (tightly regulated) blood tonicity.

Check for updates

Department of Human Movement Science, Exercise Science Program, Oakland University, Rochester, Michigan, USA

\section{Correspondence to} Dr Tamara D Hew-Butler; hew@ oakland.edu

\section{INTRODUCTION}

Dehydration is a term that generally reflects any loss of body water and linked to poor athlete performance, heat illness, skeletal muscle cramps and acute renal failure in athletes. ${ }^{1}$

Given the potential for unfavourable health and performance consequences, a number of

\section{What are the new findings?}

- A urine osmolality above $700 \mathrm{mOsmol} / \mathrm{kgH}_{2} \mathrm{O}$ would classify $>50 \%$ of athletes as dehydrated, in a spot sample hydration check, despite normal blood sodium concentration, potassium concentration and osmolality values that would confirm the athletes were euhydrated (normonatremic) at rest.

- Urine concentration, either as urine osmolality or specific gravity, should not be used as a surrogate measure for blood hydration markers in a spot sample hydration check conducted at rest.

- A urine osmolality value above $700 \mathrm{mOsmol} / \mathrm{kgH}_{2} \mathrm{O}$, and/or urine specific gravity above 1.020 , reflects urinary free water conservation and not clinically significant (intracellular) dehydration in a large cohort of collegiate athletes.

definitions have been used to define dehydration with an end goal of prevention. The American College of Sports Medicine uses non-invasive measures to define dehydration as a urine specific gravity (USG) $\geq 1.020$ and/or urine osmolality (UOsm) $\geq 700$ $\mathrm{mOsmol} / \mathrm{kgH}_{2} \mathrm{O} .{ }^{1}$ The advantage of using non-invasive measures is that they are quick, simple and easy to use in both laboratory and field settings. Studies using body weight and urine indices as outcome measures support the conclusion that athletes must drink beyond the physiological dictates of thirst to maintain adequate hydration levels. ${ }^{1}$

In contrast to non-invasive measures of hydration status, clinical medicine is reliant on blood (serum or plasma) chemistry measurements to define and subdivide dehydration into two (often related) categories: intracellular and extracellular dehydration. ${ }^{23}$ Intracellular dehydration is defined by any loss of intracellular water that induces cellular desiccation and hypertonicity (ie, increases in blood sodium concentration $\left(\left[\mathrm{Na}^{+}\right]\right)$or osmolality). ${ }^{23}$ Extracellular dehydration, which is also referred to as hypovolaemia or volume depletion, alternatively reflects any loss of 
sodium from the extracellular space that compromises plasma volume. ${ }^{2}{ }^{3}$ The distinction between intracellular and extracellular dehydration is diagnostically important when choosing the best therapeutic strategies for water lack (intracellular dehydration) and/or sodium lack (extracellular dehydration). This clinical definition also reflects the physiological tenets of fluid homeostasis, which strive to protect tonicity and tissue perfusion. ${ }^{24-6}$ Accordingly, the US Institute of Medicine states that the primary indicator of hydration status is plasma or serum osmolality ${ }^{78}$ with the maintenance of normonatremia (blood $\left[\mathrm{Na}^{+}\right]$between $135 \mathrm{mmol} / \mathrm{L}$ and $145 \mathrm{mmol} / \mathrm{L}$ ) central to this evolutionary tenet. ${ }^{69}$ Accordingly, studies using plasma osmolality ${ }^{10-13}$ or plasma volume ${ }^{14}$ as indicators of hydration status support the conclusion that thirst is an adequate stimulus to prevent intracellular and extracellular dehydration.

Investigations assessing relationships between urine concentrations versus plasma osmolality (tonicity) in athletes fail to demonstrate statistical significance that would support the utility of using urine indices as a (more practical) surrogate measure of cellular hydration. ${ }^{15-22}$ The lack of diagnostic utility in using urine indices to predict intracellular dehydration has also been verified in a large sampling of 313 older people in a clinical setting. ${ }^{8}$ While plasma osmolality remains the hallmark measure of both tonicity and water balance, ${ }^{4-6}$ derangements in serum $\left[\mathrm{Na}^{+}\right]$represent extreme clinical manifestations of fluid imbalance that require emergent treatment. ${ }^{4}$ Accordingly, athlete deaths from underhydration have been associated with hypernatremia (serum $\left.\left[\mathrm{Na}^{+}\right]>145 \mathrm{mmol} / \mathrm{L}\right),{ }^{23}$ while deaths from overhydration have been associated with hyponatremia (serum $\left.\left[\mathrm{Na}^{+}\right]<135 \mathrm{mmol} / \mathrm{L}\right) .^{24}$

The primary aim of this study is to compare blood and urine indices using two common urine-based definitions of dehydration. ${ }^{121}$ 25-27 Additionally, we chose serum $\left[\mathrm{Na}^{+}\right]$(instead of plasma osmolality) as our main outcome measure of blood tonicity to more critically reflect the clinical consequences documented in exercise-associated fatalities at the extremes of fluid imbalance. ${ }^{2324}$ The practical importance of clarifying the sport (urine) versus clinical (blood) definition of dehydration distills down to one simple-yet hotly debated-question: how much should we drink? Our hypothesis is that dehydration-and utility of using thirst as a guide to prevent dehydration-is highly dependent on the criterion used as the main outcome measure.

\section{METHODS}

This project was approved by Oakland University's Institutional Review Board (IRBNET), and written informed consent was obtained from each participant prior to data collection. Data were obtained from collegiate athletes participating in two separate projects.

\section{Project 1}

In this project (IRBNET\#888153), 40 male and female National Collegiate Athletic Association (NCAA)
Division 1 (D1) swimmers presented to the laboratory six times over the first 7 weeks of preseason (Fall) training. Testing occurred on Friday afternoons, between 14:00 and 16:00 as part of a larger project on rhabdomyolysis. Each swimmer provided a spot urine sample, and $5 \mathrm{~mL}$ of blood was withdrawn via venipuncture while in a supine position. All urine samples were analysed for USG using a URS-10 CHEMSTRIP inserted into an Uritek TC-101 urine reader (Tecodiagnostics, Anaheim, California, USA) and UOsm using a VAPRO Vapor Pressure Osmometer (Wescor, Logan, Utah, USA). Whole blood samples were analysed for serum $\left[\mathrm{Na}^{+}\right]$and potassium concentration $\left(\left[\mathrm{K}^{+}\right]\right)$using ion selective electrodes at a nearby hospital laboratory (Crittenton Hospital). Serum osmolality was assessed using a VAPRO Pressure Osmometer.

\section{Project 2}

In this screening project (IRBNET\#778936), 79 NCAA D1 athletes participating in Fall sports (women's soccer, men and women's cross country and basketball) presented to the laboratory once, preseason, for a single blood draw at a time (between 09:00 and 15:00) suitable for each team. As part of a larger project, each student-athlete provided a spot urine sample, and $5 \mathrm{~mL}$ of blood was withdrawn via venipuncture while in a supine position. All urine samples were analysed for USG using a URS-10 CHEMSTRIP inserted into an Uritek TC-101 urine reader and UOsm using a VAPRO Vapor Pressure Osmometer. Whole blood samples were analysed for $\left[\mathrm{Na}^{+}\right]$and $\left[\mathrm{K}^{+}\right]$using a Roche $9180 \mathrm{AVL}$ electrolyte analyser (Roche Diagnostics, Indianapolis, Indiana, USA). Serum osmolality was assessed using a VAPRO Pressure Osmometer.

Fluid intake was neither monitored nor measured in either project. In general, our student-athletes were not given standardised guidance on the topic of hydration and free to drink any beverage at any time. Our training room provided water bottles plus free access to a sports beverage (Gatorade), milk (plain, chocolate, strawberry and soy) and water to all student-athletes.

In both projects, all urine and serum biochemical hydration indices were measured within 2 hours of collection. Duplicate measurements were conducted in serum samples only when they appeared out of the normal reference range, with the value closest to the normal physiological range used. Blood and urine sampling occurred without restrictions on diet, hydration or activity as 'spot checks' obtained in a field setting. ${ }^{18}$ Thirst was assessed using a 10-point rating scale, with ' 0 ' representing 'not thirsty at all' and ' 10 ' representing 'extremely thirsty', either when entering the lab (project 1) or at the time of venipuncture (project 2). This rating scale was adapted from Engell ${ }^{12}$ and validated as a 9-point ${ }^{28} 29$ and 11-point rating scale $^{30}$ as well as a $10 \mathrm{~cm}$ (unmarked) visual analogue scale. ${ }^{1013}$ 
Table 1 Demographics of male and female participants from project 1 and project 2

\begin{tabular}{lllll}
\hline & & $\begin{array}{l}\text { Height } \\
(\mathbf{m})\end{array}$ & $\begin{array}{l}\text { Weight } \\
\mathbf{( k g )}\end{array}$ & $\begin{array}{l}\text { BMI } \\
\left(\mathbf{k g} / \mathbf{m}^{2}\right)\end{array}$ \\
Athlete & Participants & mean \pm SD & mean \pm SD & mean \pm SD \\
\hline $\begin{array}{l}\text { Project 1 } \\
\text { (tested }\end{array}$ & Males $(n=17)$ & $1.8 \pm 0.1^{*}$ & $77.6 \pm 6.1^{*}$ & $23.4 \pm 1.9$ \\
six times) & Females $(n=23)$ & $1.7 \pm 0.1$ & $66.3 \pm 6.3$ & $22.9 \pm 2.2$ \\
$\begin{array}{l}\text { Project 2 } \\
\text { (tested } \\
\text { once) }\end{array}$ & Males $(n=23)$ & $1.9 \pm 0.1^{*}$ & $85.7 \pm 15.5^{*}$ & $24.0 \pm 2.6$ \\
\hline
\end{tabular}

${ }^{*} \mathrm{P}<0.05$ between project 1 versus project 2 males.

$\mathrm{BMI}$, body mass index.

\section{Definitions of dehydration}

Combined data were artificially categorised into two groups, dehydrated versus hydrated athletes, based on the following two commonly used urine-based definitions of dehydration: (1) UOsm $\geq 700 \mathrm{mOsmol} / \mathrm{kgH}_{2} \mathrm{O}^{1}$ and (2) USG $\geq 1.020 .{ }^{131}$ The following variables were then compared between dehydrated versus hydrated athletes: serum $\left[\mathrm{Na}^{+}\right],\left[\mathrm{K}^{+}\right]$and osmolality; UOsm and USG; and thirst rating. Normonatremia was defined as any serum $\left[\mathrm{Na}^{+}\right]$between $135 \mathrm{mmol} / \mathrm{L}$ and $145 \mathrm{mmol} / \mathrm{L}$, with clinical (cellular) dehydration defined as any serum $\left[\mathrm{Na}^{+}\right]>145 \mathrm{mmol} / \mathrm{L}$ (hypernatremia) ${ }^{46}$ Relative overhydration was defined as any serum $\left[\mathrm{Na}^{+}\right]<135 \mathrm{mmol} / \mathrm{L}$ (hyponatremia). ${ }^{4624}$

\section{Statistics}

All data analysed using Statistica V.13 (Dell, Round Rock, Texas, USA). T-tests with unequal variance were used to analyse differences between urine markers, serum markers and thirst rating using the two urine-based thresholds that categorised athletes into dehydrated versus hydrated athlete groups. Relationships between variables were assessed using Pearson's product-moment correlations. Data reported as means $\pm \mathrm{SD}$ with statistical significance set a priori at $\mathrm{P}<0.05$.

\section{RESULTS}

For project 1 , of the 40 swimmers (23 female) that were tested six times, only one individual had missing data at one testing time point (thus $\mathrm{n}=239$, not 240). For project 2, there were 23 males and 56 females who were tested once. Demographic data from both projects detailed in table 1. Data from both projects were analysed collectively, as each data point represented 318 individual athlete 'spot checks', tested at random in an ecologically valid setting.

Table 2 depicts the hydration variables of interest for the entire cohort of spot checks $(n=318)$, divided into male $(n=125)$ and female $(n=193)$ spot checks, along with the normal range of values. On average, all biochemical variables of interest were within the normal reference range. The only statistically significant difference between male versus female spot check values was noted in USG, with females demonstrating a (mathematically) higher USG compared with males.

Table 3 depicts the analyses of hydration variables when dehydration was defined as any UOsm value $\geq 700 \mathrm{mOsoml} / \mathrm{kgH}_{2} \mathrm{O} .{ }^{1}$ Using this definition, $174(55 \%)$ of the athlete spot checks would classify these athletes as dehydrated on arrival into the laboratory. When compared with athletes classified as 'hydrated' using this definition, the 'dehydrated' athletes had statistically significant elevations in UOsm (by design), USG, serum $\left[\mathrm{Na}^{+}\right]$and thirst ratings.

Table 4 depicts the analyses of hydration variables when dehydration was defined as any USG value $\geq 1.020$. ${ }^{1}$ Using this definition, 85 (27\%) of the athlete spot checks would classify these athletes as dehydrated on arrival into the laboratory. When compared with athletes classified as 'hydrated' using this definition, the 'dehydrated' athletes had statistically significant elevations in USG (by design) and UOsm. There were no differences in any serum variable or thirst rating.

Figure 1 demonstrates the statistically significant positive relationship $(\mathrm{r}=0.18 ; \mathrm{P}<0.01)$ between serum $\left[\mathrm{Na}^{+}\right]$versus UOsm. Of note, despite the wide range of UOsm values (110-1298 mOsoml $\left./ \mathrm{kgH}_{2} \mathrm{O}\right)$, only one serum $\left[\mathrm{Na}^{+}\right]$value $(134 \mathrm{mmol} / \mathrm{L})$ was outside of the normal reference range of $135-145 \mathrm{mmol} / \mathrm{L} .{ }^{24}$ Significant correlations were also noted between serum $\left[\mathrm{Na}^{+}\right]$versus thirst rating $(\mathrm{r}=0.12 ; \mathrm{P}<0.05)$, serum $\left[\mathrm{Na}^{+}\right]$ versus serum osmolality $(\mathrm{r}=0.24 ; \mathrm{P}<0.001)$, UOsm versus

Table 2 Markers of hydration status for entire cohort $(n=318)$ and subdivided into females and males

\begin{tabular}{lllll}
\hline Variable & $\begin{array}{l}\text { Combined mean } \pm \text { SD } \\
\text { (min-max) }\end{array}$ & $\begin{array}{l}\text { Females } \\
\text { mean } \pm \text { SD } \mathbf{n = 1 9 3}\end{array}$ & $\begin{array}{l}\text { Males } \\
\text { mean } \pm \text { SD } \mathbf{n = 1 2 5}\end{array}$ & \multicolumn{1}{c}{ Normal range } \\
\hline Serum $\left[\mathrm{Na}^{+}\right](\mathrm{mmol} / \mathrm{L})$ & $139.9 \pm 2.1(134-145)$ & $139.7 \pm 2.0$ & $140.1 \pm 2.2$ & $135-145$ \\
\hline Serum $\left[\mathrm{K}^{+}\right](\mathrm{mmol} / \mathrm{L})$ & $4.4 \pm 0.3(3.6-6.4)$ & $4.4 \pm 0.3$ & $4.4 \pm 0.4$ & $3.5-5$ \\
Serum osmolality $\left(\mathrm{mOsmol} / \mathrm{kgH}_{2} \mathrm{O}\right)$ & $280.6 \pm 8.7(261-307)$ & $280.8 \pm 8.9$ & $280.2 \pm 8.3$ & $275-295$ \\
Urine osmolality $\left(\mathrm{mOsmol} / \mathrm{kgH}_{2} \mathrm{O}\right)$ & $682.7 \pm 302(110-1298)$ & $671.6 \pm 298.2$ & $699.7 \pm 308.3$ & $300-900$ \\
Urine specific gravity & $1.014 \pm 0.006(1.005-1.030)$ & $1.014 \pm 0.006$ & $1.015 \pm 0.006^{\star}$ & $1.005-1.030$ \\
Thirst rating $(0-10)$ & $4.4 \pm 1.8(0-10)$ & $4.5 \pm 1.8$ & $4.2 \pm 1.9$ & \\
\hline
\end{tabular}

${ }^{*} \mathrm{P}<0.05$ between females versus males.

The normal physiological range for each biochemical variable is listed in the last column.

serum $\left[\mathrm{K}^{+}\right]$, potassium concentration; serum $\left[\mathrm{Na}^{+}\right]$, sodium concentration. 
Table 3 Dehydration defined by urine osmolality (UOsm) whereas dehydration is any UOsm $\geq 700 \mathrm{mOsmol} / \mathrm{kg} / \mathrm{H}_{2} \mathrm{O}$, while adequately hydrated is any UOsm $<700 \mathrm{mOsmol} / \mathrm{kg} /$ $\mathrm{H}_{2} \mathrm{O}$

\begin{tabular}{|c|c|c|}
\hline Variable & $\begin{array}{l}\text { Dehydrated } \\
\text { mean } \pm S D n=174\end{array}$ & $\begin{array}{l}\text { Hydrated } \\
\text { mean } \pm S D n=144\end{array}$ \\
\hline $\begin{array}{l}\text { Serum }\left[\mathrm{Na}^{+}\right] \\
(\mathrm{mmol} / \mathrm{L})\end{array}$ & $140.3 \pm 2.0$ & $139.4 \pm 2.1^{\star \star *}$ \\
\hline $\begin{array}{l}\text { Serum }\left[\mathrm{K}^{+}\right] \\
(\mathrm{mmol} / \mathrm{L})\end{array}$ & $4.4 \pm 0.3$ & $4.4 \pm 0.4$ \\
\hline $\begin{array}{l}\text { Serum osmolality } \\
\left(\mathrm{mOsmol} / \mathrm{kgH}_{2} \mathrm{O}\right)\end{array}$ & $280.7 \pm 9.1$ & $280.4 \pm 8.0$ \\
\hline $\begin{array}{l}\text { Urine osmolality } \\
\left(\mathrm{mOsmol} / \mathrm{kgH}_{2} \mathrm{O}\right)\end{array}$ & $918.7 \pm 127.9$ & $397.4 \pm 181.0^{\star \star \star}$ \\
\hline Urine specific gravity & $1.017 \pm 0.005$ & $1.011 \pm 0.005^{\star \star \star}$ \\
\hline Thirst rating (0-10) & $4.6 \pm 1.7$ & $4.0 \pm 2.0^{\star \star}$ \\
\hline
\end{tabular}

By this definition, $55 \%$ of the athletes were dehydrated. ${ }^{*} \mathrm{P}<0.05 ;{ }^{* \star} \mathrm{P}<0.01 ;{ }^{* \star \star} \mathrm{P}<0.001$ between dehydrated versus hydrated.

serum $\left[\mathrm{K}^{+}\right]$, potassium concentration; serum $\left[\mathrm{Na}^{+}\right]$, sodium concentration.

thirst rating $(\mathrm{r}=0.20 ; \mathrm{P}<0.001)$ and $\mathrm{UOsm}$ versus USG $(\mathrm{r}=0.64 ; \mathrm{P}<0.001)$.

\section{DISCUSSION}

Urine-based definitions identified $27 \%-55 \%$ of our collegiate athletes as 'dehydrated' at the time of testing. Those athletes classified as dehydrated using urine criteria (UOsm $\geq 700 \mathrm{mOsoml} / \mathrm{kgH}_{2} \mathrm{O}$ or USG $>1.020$ ) would have subsequently been instructed to drink more fluids (above the dictates of thirst) to achieve 'adequate' hydration levels. ${ }^{12125-27}$ Conversely, none of our athletes were identified as dehydrated according to serum $\left[\mathrm{Na}^{+}\right]$measurement (figure 1 ). The maintenance

Table 4 Dehydration defined by urine specific gravity (USG) whereas dehydration is any USG $\geq 1.020$, while adequately hydrated is any USG $<1.020$

\begin{tabular}{|c|c|c|}
\hline Variable & $\begin{array}{l}\text { Dehydrated } \\
\text { mean } \pm S D \text { n=85 }\end{array}$ & $\begin{array}{l}\text { Hydrated } \\
\text { mean } \pm \text { SD } n=233\end{array}$ \\
\hline $\begin{array}{l}\text { Serum }\left[\mathrm{Na}^{+}\right] \\
(\mathrm{mmol} / \mathrm{L})\end{array}$ & $139.9 \pm 2.2$ & $139.9 \pm 2.1$ \\
\hline $\begin{array}{l}\text { Serum }\left[\mathrm{K}^{+}\right] \\
(\mathrm{mmol} / \mathrm{L})\end{array}$ & $4.4 \pm 0.4$ & $4.4 \pm 0.3$ \\
\hline $\begin{array}{l}\text { Serum osmolality } \\
\left(\mathrm{mOsmol} / \mathrm{kgH}_{2} \mathrm{O}\right)\end{array}$ & $280.6 \pm 8.3$ & $280.6 \pm 8.8$ \\
\hline $\begin{array}{l}\text { Urine osmolality } \\
\left(\mathrm{mOsmol} / \mathrm{kgH}_{2} \mathrm{O}\right)\end{array}$ & $893.4 \pm 189.7$ & $605.8 \pm 299.0^{\star \star \star}$ \\
\hline Urine specific gravity & $1.022 \pm 0.003$ & $1.011 \pm 0.004^{\star \star *}$ \\
\hline Thirst rating $(0-10)$ & $4.3 \pm 1.8$ & $4.4 \pm 1.8$ \\
\hline
\end{tabular}

By this definition, $27 \%$ of the athletes were dehydrated. ${ }^{*} \mathrm{P}<0.05 ;{ }^{* \star} \mathrm{P}<0.01 ;{ }^{* \star *} \mathrm{P}<0.001$ between dehydrated versus hydrated.

serum $\left[\mathrm{K}^{+}\right]$, potassium concentration; serum $\left[\mathrm{Na}^{+}\right]$, sodium concentration. of normonatremia-despite wide fluctuations in urine concentration-suggests that these athletes were drinking adequate amounts of fluid in response to osmotic thirst stimulation. ${ }^{41011}$ The lack of clinical sensitivity for urine indices to detect intracellular dehydration supports previous results obtained from smaller studies involving athletes/exercise ${ }^{15-22}$ and larger studies conducted in older patients ${ }^{8}$ and young children. ${ }^{32}$ The popularity of using urine indices to define 'inadequate hydration', 3334 despite a growing body of contradictory evidence, thereby raises critical concern over the apparent medicalisation of a normal physiological response (kidney water conservation). ${ }^{35} 36$

The maintenance of normonatremia has been documented previously in $80 \%$ of 2135 endurance athletes, completing a variety of races ranging from standard $(42.2 \mathrm{~km})$ marathons through Ironman Triathlons across four countries. ${ }^{37}$ With dehydration and water turnover expected to be exceedingly high immediately following prolonged endurance races, only $13 \%$ of this large cohort were hypernatremic, while $7 \%$ were hyponatremic on race finish. ${ }^{37}$ This low incidence of dysnatremia thereby underscores the strength of the osmoregulatory system, even under conditions of heightened physiological and psychological stress.

In contrast to blood indices, UOsm definitions categorised $55 \%$ (UOsm $\left.\geq 700 \mathrm{mOsmol} / \mathrm{kgH}_{2} \mathrm{O}\right)^{1}$ of our student-athletes as 'dehydrated' at the time of measurement (table 3). By design, both urine values (UOsm and USG) were significantly higher in the dehydrated versus hydrated groups. Serum $\left[\mathrm{Na}^{+}\right]$and thirst ratings also demonstrated statistically significant increases in the dehydrated versus hydrated groups. However, the mathematical difference between groups for these regulated variables $(140.3 \mathrm{mmol} / \mathrm{L}$ vs $139.3 \mathrm{mmol} / \mathrm{L}$ for serum $\left[\mathrm{Na}^{+}\right]$and 4.6 vs 4.2 for thirst) were not clinically meaningful. The high incidence of dehydration $(55 \%)$ based on UOsm criteria in the present study concurs with a study performed on 46 (26 male, 20 female) adolescent swimmers, using UOsm $\geq 700 \mathrm{mOsmol} / \mathrm{kgH}_{2} \mathrm{O}$ to define dehydration. ${ }^{25}$ Those authors found that $67 \%$ of their swimming cohort were dehydrated on rising (first morning urine sample), $78 \%$ were dehydrated immediately prior to training and thirst rating was not significantly different before $(4.4 / 10)$ versus after $(5.5 / 10)$ training. ${ }^{25}$ Thus, despite UOsm concentrations being twice as high in the dehydrated versus hydrated categories in the present study, serum biomarkers $\left(\left[\mathrm{Na}^{+}\right],\left[\mathrm{K}^{+}\right]\right.$and osmolality) and thirst perception remained remarkably stable.

Another commonly used definition to assess 'dehydration' is USG, which takes into account both urine solute mass as well as concentration. ${ }^{38}$ Using the threshold of any USG value $\geq 1.020$ to define dehydration, ${ }^{1} 27 \%$ of our athletes were classified as 'dehydrated' at the time of measurement (table 4). This incidence is much lower than previous rates demonstrated in other athletic cohorts such as $90 \%$ of 107 male adolescent soccer players measured before practice ${ }^{39}$ and $66 \%$ of 263 (138 male, 


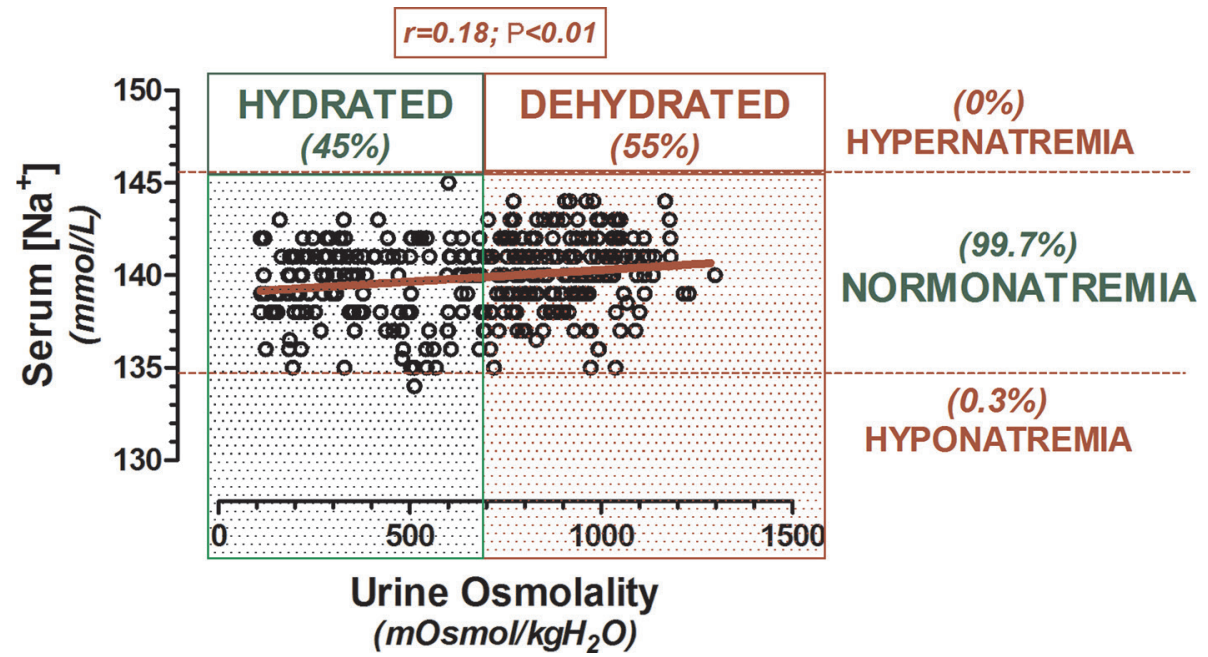

Figure 1 Graph of serum $\left[\mathrm{Na}^{+}\right]$versus urine osmolality, when all data points $(\mathrm{n}=318)$ were combined. Across the $y$-axis, no athlete demonstrated intracellular dehydration (hypernatremia; serum $\left[\mathrm{Na}^{+}\right]>145 \mathrm{mmol} / \mathrm{L}$ ), $99.7 \%$ demonstrated normonatremia (serum $\left[\mathrm{Na}^{+}\right]$between $135 \mathrm{mmol} / \mathrm{L}$ and $145 \mathrm{mmol} / \mathrm{L}$ ), while one athlete was hyponatremic (serum [ Na $\left.{ }^{+}\right]=134 \mathrm{mmol} / \mathrm{L}$ ). Across the $\mathrm{x}$-axis, $55 \%$ of athlete spot checks fell into the dehydrated range (UOsm $\geq 700 \mathrm{mOsmol} / \mathrm{kgH}_{2} \mathrm{O}$ ), while $45 \%$ fell into the hydrated range (UOsm $\left.<700 \mathrm{mOsmol} / \mathrm{kgH}_{2} \mathrm{O}\right)$. The correlation coefficient $(\mathbf{r})$ was statistically significant $(\mathrm{P}<0.01)$, despite serum $\left[\mathrm{Na}^{+}\right]$explaining only $3 \%$ of the variance in urine osmolality. serum $\left[\mathrm{Na}^{+}\right]$, sodium concentration; UOsm, urine osmolality.

125 female) NCAA D1 athletes who provided random urine samples. ${ }^{40}$ Similar to the UOsm findings, there were no mathematical or clinically relevant differences in either serum markers $\left(\left[\mathrm{Na}^{+}\right],\left[\mathrm{K}^{+}\right]\right.$and osmolality) or thirst rating, since blood tonicity is a physiologically regulated variable.

The previous literature has been consistent with our blood versus urine findings, demonstrating significant relationships between urine markers (such as USG vs UOsm $)^{22} 38$ but not between urine versus blood markers of hydration status $\left(\left[\mathrm{Na}^{+}\right]\right.$and osmolality). ${ }^{8} 2122$ The confounding effects of diet, the timing of fluid intake and the renal response to exercise likely contribute to the poor prognostic utility of using urine indices as surrogate markers for water and sodium homeostasis (plasma tonicity or volume status) ${ }^{41}$ In contrast to osmoregulatory thirst and arginine vasopressin (AVP) stimulation, urine concentration is not a regulated physiological variable associated with fluid homeostasis. ${ }^{4-6} 104243$ Urine volume and solute concentration are renal effector responses that are largely subservient to circulating plasma AVP levels. ${ }^{453}$ Copious urinary free water excretion is reflective of either: (1) AVP suppression, which largely occurs when fluid intake is in excess of osmoregulatory need, ${ }^{4}$ or (2) AVP antagonism at the V2 receptor, triggering dilute urine with cellular dehydration. ${ }^{44}$ Clinically speaking, AVP suppression and antagonism characterise central and nephrogenic diabetes insipidus, both of which are successfully compensated by osmotically driven thirst stimulation to maintain tonicity balance. ${ }^{4}$

Drinking according to the dictates of thirst will thereby prevent cellular dehydration. Drinking to keep urine clear or maintain body weight may lead to overhydration. ${ }^{24}$ Accordingly, drinking above thirst has been associated with a $33 \%-57 \%$ incidence of hyponatremia in professional rugby players tested after match play, field and gym training. ${ }^{45}$ Thus, although urine concentration may be a useful measurement tool, caution is advised against the potential for overzealous adherence to fluid intake guidelines based on urine or any other hypotonic fluid secretion, which may overshoot osmoregulatory need or renal excretion capabilities.

Limitations of our study include an inability to control fluid intake or standardise exercise prior to testing. Our inability to control fluid intake or timing may have contributed to delays in the adjustment of urine indices to plasma changes from fluid absorption, as proposed elsewhere. ${ }^{15} 18$ Previous research has also shown that exercised-induced fluid losses-without clinically significant dehydration-may have significant effects on other important physiological variables such as heart rate, core temperature, sweat loss, rating of perceived exertion and skeletal muscle metabolism, which may hinder physical and mental performance. ${ }^{146} 47$ However, despite these clear limitations and need for further study, we believe that these data provide a robust 'snapshot' of the typical collegiate athlete who is able to preserve cellular size (normonatremia) despite a wide range of urine concentrations, exercise and hydration habits.

In summary, normonatremia was maintained in $99.7 \%$ of this random sample of hydration spot checks performed at rest. UOsm $\geq 700 \mathrm{mOsmol} / \mathrm{kgH}_{2} \mathrm{O}$ classified $55 \%$, while USG $\geq 1.020$ classified $27 \%$ of athletes as dehydrated at the time of testing. This discrepancy between serum versus urine indices likely reflect the differences between using a physiologically regulated versus non-physiologically regulated variables to define dehydration. Since thirst is a physiologically regulated variable of fluid homeostasis, drinking to thirst would be an appropriate fluid intake strategy using serum or plasma 
DEHYDRATION

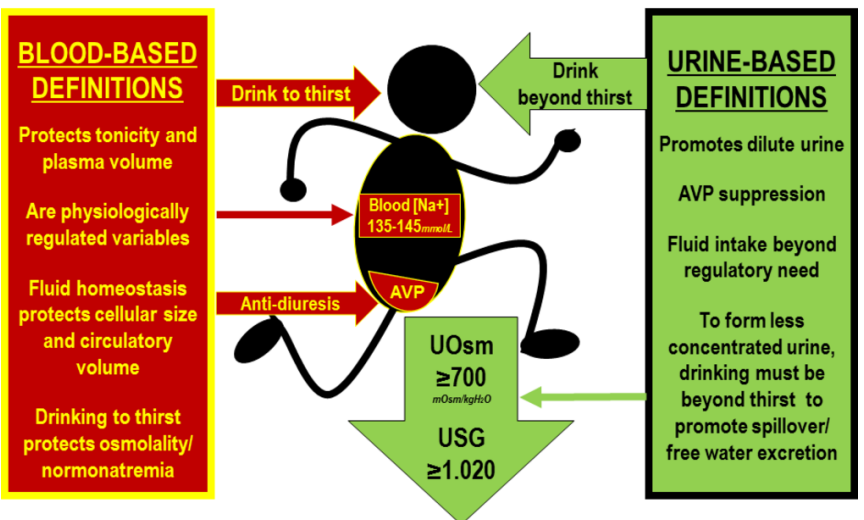

Figure 2 Infographic representing an athlete and summarising how the definition of dehydration that is used (blood vs urine indices) affects whether thirst is (or is not) an appropriate hydration strategy to prevent dehydration in a rested state (pre-exercise), according to the threshold used. UOsm, urine osmolality; USG, urine specific gravity.

criterion to prevent hypernatremia or hyponatremia, at least during resting conditions (pre-exercise). However, according to urine output based definitions of dehydration, drinking above the dictates of thirst is required to suppress AVP and promote a clear and copious free water excretion (aquaresis). Thus, the definition of dehydration varies greatly within various study populations, with subsequent hydration advice subservient to the definition that is used. Figure 2 summarises how the different definitions may yield differential hydration advice from a physiological perspective, at least during a rested state. It is important to emphasise that these data do not question the potential deleterious effects of dehydration-nor drinking to thirst-on performance but rather questions the utility of using urine concentration as a surrogate marker for clinical dehydration in routine student-athlete urine spot checks.

Acknowledgements The authors would like to thank Barb Ledin MT (ASCP) and Crittenton Hospital for assisting with the lab work, Brigid Byrd for coordinating test schedules, Gregory Byrd, Raychel Rusnak, Kristin Landis-Piwowar and Lisa DeCeuninck for assistance with venipuncture. Lastly, we offer heartfelt thanks to all of the student-athletes who enthusiastically participated in these trials. We honour your energy, benevolence and sacrifice through this work.

Contributors TDH-B participated in study design, data acquisition and analyses and drafting of the manuscript. CE participated in data acquisition, analyses and drafting of the manuscript. JB, MR and MVM participated in data acquisition. All authors participated in revising the manuscript, and all authors gave final approval on the paper.

Funding This study was supported by Oakland University's Provost's undergraduate (MVM) and graduate (MR) awards and Prevention Research Center award (TDH-B).

Competing interests None declared.

Ethics approval Michigan, USA.

Provenance and peer review Not commissioned; externally peer reviewed.

Open Access This is an Open Access article distributed in accordance with the Creative Commons Attribution Non Commercial (CC BY-NC 4.0) license, which permits others to distribute, remix, adapt, build upon this work non-commercially, and license their derivative works on different terms, provided the original work is properly cited and the use is non-commercial. See: http://creativecommons.org/ licenses/by-nc/4.0/

(c) Article author(s) (or their employer(s) unless otherwise stated in the text of the article) 2018. All rights reserved. No commercial use is permitted unless otherwise expressly granted.

\section{REFERENCES}

1. Sawka MN, Burke LM, Eichner ER, et al. American college of sports medicine position stand. Exercise and fluid replacement. Med Sci Sports Exerc 2007;39:377-90.

2. Mange K, Matsuura D, Cizman B, et al. Language guiding therapy: the case of dehydration versus volume depletion. Ann Intern Med 1997;127:848-53.

3. McGee S, Abernathy WB, Simel D. Is this patient hypovolemic? JAMA 1999;281:1022-9.

4. Verbalis JG. Disorders of body water homeostasis. Best Pract Res Clin Endocrinol Metab 2003;17:471-503.

5. Bourque CW. Central mechanisms of osmosensation and systemic osmoregulation. Nat Rev Neurosci 2008;9:519-31.

6. Sterns RH. Disorders of plasma sodium. N Engl J Med 2015;372:1269.

7. Institute of Medicine of the National Academies. Dietary reference intakes for water, potassium, sodium, chloride, and sulfate. Washington D.C: The National Academies Press, 2004.

8. Hooper L, Bunn DK, Abdelhamid A, et al. Water-loss (intracellular) dehydration assessed using urinary tests: how well do they work? Diagnostic accuracy in older people. Am J Clin Nutr 2016;104:121-31.

9. Beets I, Temmerman L, Janssen T, et al. Ancient neuromodulation by vasopressin/oxytocin-related peptides. Worm 2013;2:e24246.

10. Thompson CJ, Bland J, Burd J, et al. The osmotic thresholds for thirst and vasopressin release are similar in healthy man. Clin Sci 1986;71:651-6.

11. Thompson CJ, Selby P, Baylis PH. Reproducibility of osmotic and nonosmotic tests of vasopressin secretion in men. Am J Physiol 1991;260(3 Pt 2):R533-R539.

12. Engell DB, Maller O, Sawka MN, et al. Thirst and fluid intake following graded hypohydration levels in humans. Physiol Behav 1987;40:229-36.

13. Rolls BJ, Wood RJ, Rolls ET, et al. Thirst following water deprivation in humans. Am J Physiol 1980;239:R476-R482.

14. Brown MB, McCarty NA, Millard-Stafford M. High-sweat $\mathrm{Na}+$ in cystic fibrosis and healthy individuals does not diminish thirst during exercise in the heat. Am J Physiol Regul Integr Comp Physiol 2011;301:R1177-R1185

15. Armstrong LE, Maresh CM, Castellani JW, et al. Urinary indices of hydration status. Int J Sport Nutr 1994;4:265-79.

16. Francesconi RP, Hubbard RW, Szlyk PC, et al. Urinary and hematologic indexes of hypohydration. J Appl Physiol 1987;62:1271-6.

17. Bartok C, Schoeller DA, Sullivan JC, et al. Hydration testing in collegiate wrestlers undergoing hypertonic dehydration. Med Sci Sports Exerc 2004;36:510-7.

18. Oppliger RA, Magnes SA, Popowski LA, et al. Accuracy of urine specific gravity and osmolality as indicators of hydration status. Int $J$ Sport Nutr Exerc Metab 2005;15:236-51.

19. Singh NR, Peters EM. Markers of hydration status in a 3-day trail running event. Clin J Sport Med 2013;23:354-64.

20. Kovacs EM, Senden JM, Brouns F. Urine color, osmolality and specific electrical conductance are not accurate measures of hydration status during postexercise rehydration. J Sports Med Phys Fitness 1999;39:47-53.

21. Sommerfield LM, McAnulty SR, McBride JM, et al. Validlty of urine specific gravity when compared with plasma osmolality as a measure of hydration status in male and female NCAA Collegiate athletes. J Strength Cond Res 2016;30:2219-25.

22. Popowski LA, Oppliger RA, Patrick Lambert G, Patrick LG, et al. Blood and urinary measures of hydration status during progressive acute dehydration. Med Sci Sports Exerc 2001;33:747-53.

23. From the centers for disease control and prevention. hyperthermia and dehydration-related deaths associated with intentional rapid weight loss in three collegiate wrestlers-north carolina, Wisconsin, and Michigan, november-december 1997. JAMA 1998;279:824-5.

24. Hew-Butler T, Rosner MH, Fowkes-Godek S, et al. Statement of the 3rd international exercise-associated hyponatremia consensus development conference, carlsbad, California, 2015. Br J Sports Med 2015;49:1432-46. 
25. Adams JD, Kavouras SA, Robillard Jl, et al. Fluid balance of adolescent swimmers during training. J Strength Cond Res 2016;30:621-5.

26. Arnaoutis G, Kavouras SA, Angelopoulou A, et al. Fluid balance during training in elite young athletes of different sports. J Strength Cond Res 2015;29:3447-52.

27. Kavouras SA, Johnson EC, Bougatsas D, et al. Validation of a urine color scale for assessment of urine osmolality in healthy children. Eur J Nutr 2016;55:907-15.

28. Maresh CM, Gabaree-Boulant CL, Armstrong LE, et al. Effect of hydration status on thirst, drinking, and related hormonal responses during low-intensity exercise in the heat. $J$ Appl Physiol 2004;97:39-44.

29. Cheung SS, McGarr GW, Mallette MM, et al. Separate and combined effects of dehydration and thirst sensation on exercise performance in the heat. Scand J Med Sci Sports 2015;25 Suppl 1(Suppl 1):104-11.

30. Dion T, Savoie FA, Asselin A, et al. Half-marathon running performance is not improved by a rate of fluid intake above that dictated by thirst sensation in trained distance runners. Eur J Appl Physiol 2013;113:3011-20.

31. Casa DJ, Armstrong LE, Hillman SK, et al. National athletic trainers' association position statement: fluid replacement for athletes. J Ath Train 2000;35:212-24.

32. Steiner MJ, Nager AL, Wang VJ. Urine specific gravity and other urinary indices: inaccurate tests for dehydration. Pediatr Emerg Care 2007;23:298-303

33. Chang T, Ravi N, Plegue MA, et al. Inadequate hydration, BMI, and obesity among us adults: NHANES 2009-2012. Ann Fam Med 2016;14:320-4.

34. Kenney EL, Long MW, Cradock AL, et al. Prevalence of inadequate hydration among us children and disparities by gender and race/ ethnicity: national health and nutrition examination survey, 20092012. Am J Public Health 2015;105:e113-8.

35. McCartney M. Margaret McCartney: hydration, common sense, and evidence. BMJ 2017;359:j4642.

36. Hew-Butler T. EAH Consensus Panel 2015. Inadequate hydration or normal body fluid homeostasis? Am J Public Health 2015;105:e5-6.
37. Noakes TD, Sharwood K, Speedy D, et al. Three independent biological mechanisms cause exercise-associated hyponatremia: evidence from 2,135 weighed competitive athletic performances. Proc Natl Acad Sci U S A 2005;102:18550-5.

38. Armstrong LE, Soto JA, Hacker FT, et al. Urinary indices during dehydration, exercise, and rehydration. Int J Sport Nutr 1998;8:345-55

39. Arnaoutis G, Kavouras SA, Kotsis YP, et al. Ad libitum fluid intake does not prevent dehydration in suboptimally hydrated young soccer players during a training session of a summer camp. Int J Sport Nutr Exerc Metab 2013;23:245-51.

40. Volpe SL, Poule KA, Bland EG. Estimation of prepractice hydration status of national collegiate athletic association division I athletes. J Athl Train 2009;44:624-9.

41. Cheuvront SN, Kenefick RW, Zambraski EJ. Spot urine concentrations should not be used for hydration assessment: a methodology review. Int J Sport Nutr Exerc Metab 2015;25:293-7.

42. McKenna K, Thompson C. Osmoregulation in clinical disorders of thirst appreciation. Clin Endocrinol 1998;49:139-52.

43. Robertson GL. Abnormalities of thirst regulation. Kidney Int 1984;25:460-9.

44. Hew-Butler T, Hummel J, Rider BC, et al. Characterization of the effects of the vasopressin V2 receptor on sweating, fluid balance, and performance during exercise. Am J Physiol Regul Integr Comp Physiol 2014;307:R366-R375.

45. Jones BL, O'Hara JP, Till K, et al. Dehydration and hyponatremia in professional rugby union players: a cohort study observing english premiership rugby union players during match play, field, and gym training in cool environmental conditions. J Strength Cond Res 2015;29:107-15.

46. Logan-Sprenger HM, Heigenhauser GJ, Killian KJ, et al. Effects of dehydration during cycling on skeletal muscle metabolism in females. Med Sci Sports Exerc 2012;44:1949-57.

47. Logan-Sprenger HM, Heigenhauser GJ, Jones GL, et al. Increase in skeletal-muscle glycogenolysis and perceived exertion with progressive dehydration during cycling in hydrated men. Int J Sport Nutr Exerc Metab 2013;23:220-9. 